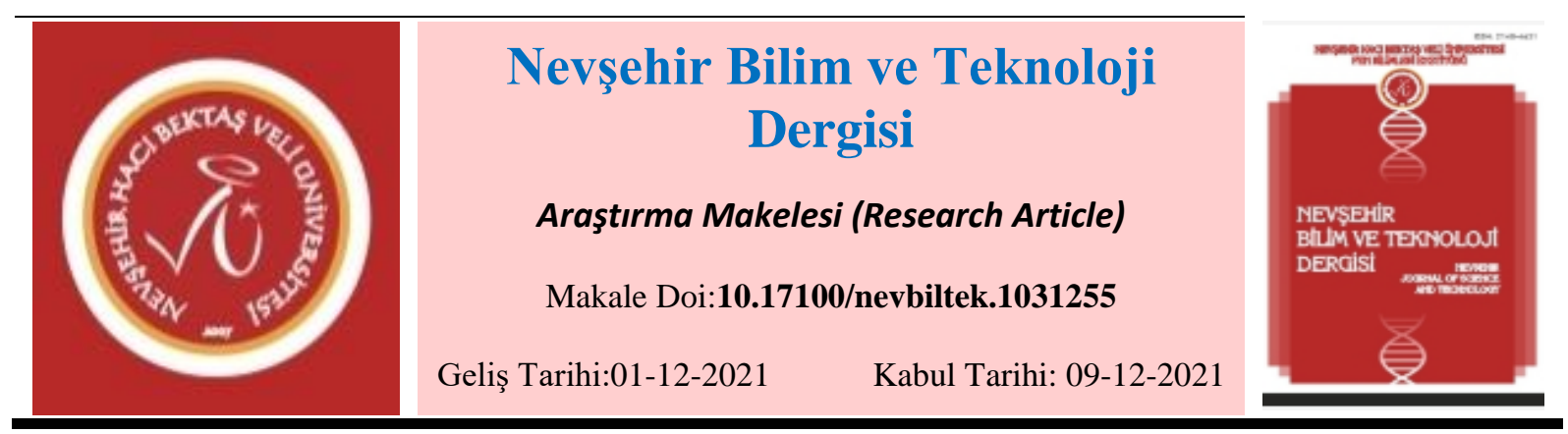

\title{
Hastane Çalışanlarının Halkla İlişkiler Uygulamalarına Yönelik Görüşleri: Bir Kamu Hastanesi Örneği
}

\author{
Gözde YEŞiLAYDIN ${ }^{1}$, Bayram GÖKTAŞ²*, Deniz Tugay ARSLAN ${ }^{3}$ \\ ${ }^{1}$ Eskişehir Osmangazi Üniversitesi, Sağllk Bilimleri Fakültesi, Sağlık Yönetimi Bölümü \\ ORCID ID: 0000-0002-2901-6474 \\ ${ }^{2}$ Ankara Üniversitesi Sağlık Bilimleri Fakültesi Să̆llk Yönetimi Bölümü \\ ORCID ID: 0000-0003-0126-4801 \\ ${ }^{3}$ Eskişehir Osmangazi Üniversitesi, Sağllk Bilimleri Fakültesi, Sağlık Yönetimi Bölümü \\ ORCID ID: 0000-0002-9654-2263
}

$\ddot{0 z}$

Halka ilişkiler kavramı her ne kadar kurumun hizmet sunumundaki hedef kitleye yönelik çalışmalar gibi algılansa da kurum çalışanlarını da kapsamalıdır. Sağlık hizmeti sunan kurumlarda çalışan personelin halkla ilişkiler faaliyetlerini nasıl algıladıkları ve memnuniyet düzeyleri bu alanda planlanacak geliştirme faaliyetlerine yön verebilir. Bu kapsamda hem merkez hem de ilçe hastanelerinin verileri önemlidir. Bu çalışmada Ankara'daki bir ilçede Sağlık Bakanlığı'na bağlı bir hastanenin çalışanları tarafından hastanenin halkla ilişkilerinin faaliyetlerinin nasıl algılandığını ve memnuniyet düzeylerini belirlemek amaçlanmıştır. Kesitsel ve tanımlayıcı düzendeki çalışmanın evreni hastanede çalışan 128 personelden oluşmaktadır. Araştırmaya katılmak için gönüllü olan 96 personelin anket uygulanmıştır. Araştırmadan elde edilen verilere göre katılımcıların \%51'i erkek, \%69,8'i evli, \%53,1'i yüksekokul/fakülte mezunu, \%52,1'i 27-37 yaş arasındadır. \%51'i sağlık personeli iken, \%49'u idari personeldir. Katılımcıların \%59,4'ü kurumda 2-9 yıldır; \%53,1'i ise meslekte 4-14 yıldır çalışmaktadır. Kurumda çalışma süresi ortalaması 4,79 $\pm 4,47$ olup, en az 1 en çok 24 yıldır kurumda çalışmaktadırlar. Meslekte çalışma süresi ortalaması ise 9,51 $\pm 6,67$ olup, en az 1 ve en çok 27 yıldır meslekte çalışmaktadırlar. Halkla ilişkiler faaliyetlerine yönelik görüşlerden en yüksek ortalama değer "sağlık personelinin empati yapması gerektiğine inanıyorum" ifadesine; en düşük ortalama değer ise "hastanemizde olumlu ya da olumsuz gerekli tüm bilgiler çalışanlarla paylaşılır" ifadesine aittir. Cinsiyet, yaş grubu, kurumda çalışma yılı ve meslekte çalışma yılı değişkenleri ile halkla ilişkiler faaliyetlerine ilişkin görüşler arasında bulunan fark istatistiksel olarak anlamlıdır $(\mathrm{p}<0,05)$. Medeni durum, öğrenim durumu ve görev değişkenleri ile halkla ilişkiler faaliyetlerine ilişkin görüşler arasında ise anlamlı bir fark bulunmamıştır.

Anahtar Kelimeler: Halkla ilişkiler; Hastane; Sağlık Çalışanı; İletişim

* Sorumlu yazar e-mail: bgoktas@ankara.edu.tr 


\title{
Views Of Hospital Personnel On Public Relations Practices: A Public Hospital Sample
}

\begin{abstract}
Although the concept of public relations is perceived as related to the target audience in the service delivery of the institution, it should also cover the personnel of the relevant institution. How the personnel working in institutions that provide health services perceive their public relations practices and their satisfaction levels can guide the development actions to be planned in this area. In this context, the data of both central and district hospitals are important. In this study, it is aimed to determine how the public relations practices of the hospital are perceived by the personnel of a hospital affiliated to the Ministry of Health in a district in Ankara and their satisfaction levels. The universe of the cross-sectional and descriptive study consists of 128 personnel working in the hospital. A questionnaire was applied to 96 personnel who volunteered to participate in the research. According to the data obtained from the research, $51 \%$ of the participants were males, $69.8 \%$ were married, $53.1 \%$ were college/faculty graduates, $52.1 \%$ were between the ages of $27-37$. While $51 \%$ were health personnel, $49 \%$ were administrative personnel. 59.4\% of the participants had been in the institution for 2-9 years; $53.1 \%$ of them had been working in the profession for 4-14 years. The average working time in the institution was $4.79 \pm 4.47$, and they had been working in the institution for at least 1 and at most 24 years. The average years of experience in the profession was $9.51 \pm 6.67$, and they had been working in the profession for at least 1 and at most 27 years. The highest average value among the items regarding the views on public relations practices was "I believe that health personnel should have empathy"; the lowest average value belonged to the statement "all necessary information, positive or negative, is shared with the employees in our hospital". The difference between the variables of gender, age group, years of experience in the institution and years of experience in the profession and opinions on public relations activities was statistically significant $(p<0.05)$. There was no significant difference between marital status, educational status and job variables and opinions on public relations practices.
\end{abstract}

Keywords: Public Relations, Hospital, Healthcare Professional, Communication

\section{Giriș}

Kaliteli sağlı hizmeti sunmak için gerekli olan teknik altyapı (bina, tıbbi cihaz, donanım vb.) ve personel (doktor, hemşire, idari personel vb.) tek başına yeterli değildir. Bu üretim faktörlerinin rasyonel kullanımı için doğru tasarlanmış bir sistem, yönetim ve organizasyon yapısının oluşturulması gerekir. Söz konusu yapı içerisinde olmazsa olmaz faktörlerden biri de halkla ilişkiler birimidir [1]. Hastaneler birçok faaliyet alanının ve farklı disiplinlerin birlikte düzenli bir işbirliği ve çalışma programı içinde hizmet sunumu yaptığı kurumlardır. Bu karmaşık yapıların etkin yönetimi ve başarılı bir hizmet sunumu için halkla ilişkiler faaliyetleri büyük bir önem arz eder [2]. Bu önem son yıllara doğru iyice anlaşılmış olup, kar amacı gütsün ya da gütmesin birçok sağlık kurumu ve hastane halkla ilişkiler faaliyetlerine daha çok önem vermeye başlamış, bu konudaki çalışmalarını hızlandırmıştır.

Hastaneler için toplumsal ilişkiler ve hedef kitle son derece önemlidir. Belirsizlikleri yönetmek, kaygı ve endişeleri gidermek, sorunları çözmek gibi yaklaşımların hastane ile hasta ve hasta yakınları arasındaki ilişkilerin kalitesini etkileyebilmektedir. Bunun için hasta ve hasta yakınları kendi düşünce ve fikirlerini rahatça ifade edebilmelidir [3]. Hastalar ve yakınları, yaşadıkları stresi çoğu kez gizlemekte, sıkıntılarından söz etmemekte ya da bu tür durumlarını kabule yanaşmama eğilimi göstermektedirler. Sağlık personeline düşen bu durumun farkındalığını anlayarak, buna neden olan sorunları ortaya çıkarmak ve sonuç olarak bunları hastayla birlikte çözebilme yolunu seçmek olmalıdır [4,5].

Hastaneler, çok geniş hedef kitlelere sahiptirler. Hedef kitlenin birbirinden oldukça farklı değerlere sahip olması nedeniyle hastalarla hastane arasında işbirliğinin sağlanmasına yönelik yapılan iletişim sürecinin değeri bu kurumlarda halkla ilişkileri daha da önemli kılmaktadır [6]. Sağlık sektöründe gerçekleşen yapısal değişimler, hastanelerin karmaşık yapısı, sağılı alanındaki yoğun uzlaşma, tıbbi terminoloji nedeniyle ortaya çıkabilen dil 
Nevşehir Bilim ve Teknoloji Dergisi (2021), 10(2) 135-143

sorunu, bürokratik işlemlerin varlığı, asimetrik bilgi mevcudiyeti, sağlık harcamalarının kontrol atına alınması yönünde baskılar ve yönetimin profesyonelleşmesi hastanelerde halkla ilişkilerin önemini arttıran temel nedenler arasındadır [7].

Halkla ilişkiler bir örgütle hedef kitleleri arasında iyi niyeti ve karşlıklı anlayışı oluşturmaya ve sürdürmeye yönelik planlı ve sürekli çabadır [8]. Her ne kadar halkla ilişkiler denince sadece hastalar için oluşturulan 'reklam, danışma, şikayet' sistemi gibi bir durum algılansa da halkla ilişkilerin çok geniş bir çalışma alanı vardır. Kurumların yaptığı tüm faaliyetlerin başarıı bir şekilde sunumu için halkla ilişkiler birimi önemli bir görev üstlenir. Hastalarla iletişim kurulması, memnuniyetin ve tercih edilme oranının artırılmasına yönelik faaliyetleri, tedarikçi firmalarla iletişim, basın bilgilendirmeleri ve basınla iletişim, koruyucu hizmetler ve olağanüstü durumlara yönelik kampanya ve faaliyetler gibi pek çok durumun yönetiminde halkla ilişsiler önemli roller üstlenir [2,9].

Hastanelerde halkla ilişkiler çalışmaları ile kazanılan bilgiler, yönetim faaliyetinde bulunanlara kurumun son durumunu çalışan personellerin gözü ile görmelerine yardımcı olarak, sorunların saptanmasına katkı sağlayacaktır. Hastanelerde çalışan çok farklı özelliklere sahip hedef kitlelere yönelik etkin ya da ikna edici iletişim sürecinin örgütlenmesi, etkin çalıştırılması ve personel ile hastalar arasındaki iletişimin örgütsel performansı arttırıcı yönde yönlendirilmesi, hastanelerde halkla ilişkileri önemli kılmaktadır [10]. Halkla ilişkiler çalışmaları hastanelerin başarııı bir şekilde yönetilmesi esasına dayanan bir kavram olup, sadece hastalara ve diğer dış kurum ve kuruluşlara yönelik değildir. Aynı zamanda kurumda çalışan personel açısından da önemlidir. Hasta memnuniyeti kadar çalışan memnuniyeti ve çalışanların kurumla ilgili algıları da halkla ilişkilerin çalışma alanına girer [2,11].

Halkla ilişkiler faaliyetlerinin başarılı bir şekilde yerine getirilmesi için hem iç hem de dış paydaşlarla olan ilgili faaliyetlere odaklanılması gerekir. İç paydaşlara yönelik halkla ilişkiler faaliyetleri "kurum içi halkla ilişkiler" olarak da adlandırılmaktadır. Hastane personeli ile hasta ve hasta yakınlarının temas yüzeylerinin geniş olması nedeniyle, hastane dışındaki halkla ilişkiler faaliyetlerinde başarılı olabilmek için kurum içi halkla ilişkiler faaliyetlerinin doğru yönetilmesi gerekmektedir. Çünkü hastanenin çevresi ile ilişki kurması hastane personeli aracılığıyla gerçekleşmektedir [5].

Halkla ilişkilere yönelik bir tanımda çalışanlar özellikle vurgulanmıştır. Tanıma göre halkla ilişkiler ‘bir firmayl, kurumu, fikri ya da markayı en başta çalışanlarına, sonra hedeflenen kitlelere benimseten, tanıtan, sevdiren, güvendiren, hakkinda olumlu bir izlenim, imaj yaratarak onu satın almaya teşvik eden, sevgi üzerine kurulmuş, araştırılmış, amaçları, stratejileri belirlenmiş, planlanmış ve uygulamaya koyulmuş çalışmalar' dır [12]. Tanımdan da anlaşılacağı üzere hastanelerdeki halkla ilişkiler faaliyetleri sadece hasta ve hasta yakınlarıyla ilgili olmayıp çalışanlarında sürece dahil edildiği kritik bir faaliyettir. Hastane için önemi büyük olan halkla ilişkiler faaliyetlerinin personel tarafindan nasıl algılandığı ve bu faaliyetlere ne kadar önem verildiği halkla ilişkiler biriminin yaptığı çalışmalar kadar önemlidir. Diğer bir deyişle personelin halkla ilişkilere bakışı bir anlamda hastane yönetiminin halkla ilişkiler birime verdiği desteği ifade etmektedir [7].

Literatür tarandığında sağlık alanında hizmet sunan kurumlarda halka ilişkiler çalışmalarının daha çok halka yönelik olduğu görülmüş olup, bu konuda kurum çalışanlarının alg1 ve memnuniyetlerinin yeterince incelenmediği, az sayıda çalışma olduğu görülmüştür. Bu çalışmalar ise il merkezlerinde yoğunlaşmaktadır. İlçelerde kurulmuş olan hastaneler hakkında veri olmaması dikkat çekicidir. Sağlık kuruluşlarında halkla ilişkilerin değerinin ortaya çıkarılması için öncelikle kurumsal halkla ilişkilerin tanımlanması, kurumsal halkla ilişkilerinin 
Nevşehir Bilim ve Teknoloji Dergisi (2021), 10(2) 135-143

kurumsal sonuçlarla ilişkilendirilmesi gerekmektedir [3]. Dolayısıyla kurum çalışanlarının da halkla ilişkiler faaliyetlerine dahil edilmesi ve görüşlerinin değerlendirilmesi gerekmektedir. $\mathrm{Bu}$ nedenle çalışma ilçelerde kurulmuş olan hastanelerin halka ilişkiler çalışmalarının kurum çalışanları tarafından nasıl algılandığını belirlemek üzere Ankara'daki bir ilçe hastanesinde yapılmıştır.

\section{Yöntem}

\subsection{Araştırmantn Amact}

$\mathrm{Bu}$ araştırma, Ankara iline bağlı bir ilçede faaliyet gösteren bir kamu hastanesinde yürütülen halkla ilişkiler uygulamalarına ilişkin hastane çalışanlarının görüşlerini değerlendirmek amacıyla yapıllmıştır. Bu amaç doğrultusunda ilgili hastanede halkla ilişkiler çalışmaları ile ilgili hem sağlı personelinin hem de idari personelin görüşleri alınmıştır.

\subsection{Araştırmantn Evreni ve Örneklemi}

Araştırmanın evrenini Ankara iline bağlı bir ilçede faaliyet gösteren bir kamu hastanesinde görev yapan 128 personel oluşturmaktadır. Çalışma kapsamında örneklem seçilmemiş olup, tüm personele ulaşmak hedeflenmiştir. Araştırmaya katılmaya gönüllü olan 96 personelin konu ile ilgili görüşleri değerlendirilmiştir. Araştırmanın yapılması için hastane yönetiminden yazılı izin alınmış ve çalışanların katılımında gönüllülük esas alınmıştır.

\subsection{Veri Toplama Aracı}

Veri toplama aracı olarak anket yöntemi kullanılmıştır. Anket, iki bölümden oluşmaktadır. Birinci bölümde katılımcılara ilişkin sosyodemografik özellikler ve tanımlayıcı bilgiler içeren soru formu; ikinci bölümde ise Bahadır (2010) tarafından literatür incelenerek hazırlanan anket formu kullanılmıştır. Sorulara ilişsin değerlendirmede "kesinlikle katılmıyorum" (1) ve "kesinlikle katılıyorum" (5) esas alınmıştır.

\subsection{Verilerin Analizi}

Katılımcıların sosyo-demografik ve tanımlayıcı özelliklerini belirlemek, ilgili hastanenin halkla ilişkiler uygulamalarına yönelik görüşlerini değerlendirmek amacıyla tanımlayıcı istatistiklerden (frekans, ortalama, standart sapma, medyan, minimum, maksimum) yararlanılmıştır. Verilerin normal dağı̆lıma uygunluğu test edilmiş ve normal dağılım göstermedikleri sonucuna ulaşılmıştır. Veriler, Mann-Whitney U ve Kruskal-Wallis testleri ile analiz edilmiş olup, anlamlılık düzeyi $\mathrm{p}<0,05$ olarak kabul edilmiştir.

\section{Bulgular}

Katılımcıların sosyodemografik özellikleri ile tanımlayıcı bilgilerine ilişkin sayısal ve yüzdesel dağılımlar Tablo 1'de sunulmuştur. Katılımcıların \%51'i erkek, \%69,8'i evli, \% 53,1'i yüksekokul/fakülte mezunu, \%52,1'i 27-37 yaş arasındadır. Yaş ortalamaları 32,75 $\pm 7,47$ olup, yaşları 19 ve 51 arasında değiş̧mektedir. Ayrıca $\% 51$ ' $\mathrm{i}$ sağlı personeli iken, \% 49'u idari personeldir. Katılımcıların \%59,4'ü kurumda 2-9 yıldır; \%53,1'i ise meslekte 4-14 yıldır çalışmaktadır. Kurumda çalışma süresi ortalaması 4,79 $\pm 4,47$ olup, en az 1 en çok 24 yıldır kurumda çalışmaktadırlar. Meslekte çalışma süresi ortalaması ise 9,51 $\pm 6,67$ olup, en az 1 ve en çok 27 yıldır meslekte çalışmaktadırlar (Tablo 1). Halkla ilişkiler faaliyetlerine yönelik görüşlerden en yüksek ortalama değer "sağlık personelinin empati yapması gerektiğine inanıyorum" ifadesine; en düşük ortalama değer ise "hastanemizde olumlu ya da olumsuz gerekli tüm bilgiler çalışanlarla paylaşıllır” ifadesine aittir (Tablo 2).

Katılımcıların sosyodemografik özellikleri ile ilgili hastanenin halkla ilişkiler faaliyetlerine ilişkin görüşleri arasında istatistiksel olarak anlamlı bir fark olup olmadığı incelenmiş̧tir. Buna göre cinsiyet, yaş grubu, 


\section{Nevşehir Bilim ve Teknoloji Dergisi (2021), 10(2) 135-143}

kurumda çalışma yılı ve meslekte çalışma yılı değişkenleri ile halkla ilişkiler faaliyetlerine ilişkin görüşler arasında bulunan fark istatistiksel olarak anlamlıdır $(\mathrm{p}<0,05)$. Medeni durum, öğrenim durumu ve görev değişkenleri ile halkla ilişkiler faaliyetlerine ilişkin görüşler arasında ise anlamlı bir fark bulunmamıştır.

Tablo 1. Katılımcılara ilişkin sosyodemografik özellikler ve tanımlayıcı bilgiler

\begin{tabular}{|c|c|c|c|}
\hline Değişkenler & & Sayı (n) & Yüzde (\%) \\
\hline \multirow{2}{*}{ Cinsiyet } & Kadın & 47 & 49,0 \\
\hline & Erkek & 49 & 51,0 \\
\hline \multirow[t]{4}{*}{ Yaş } & 26 ve alt1 & 22 & 22,9 \\
\hline & $27-37$ & 50 & 52,1 \\
\hline & 38 yaş ve üzeri & 24 & 25,0 \\
\hline & Yaş Ort. \pm ss: $32,75 \pm 7$ & 51) & \\
\hline \multirow[t]{2}{*}{ Medeni Durum } & Evli & 67 & 69,8 \\
\hline & Bekar & 29 & 30,2 \\
\hline \multirow[t]{3}{*}{ Öğrenim Durumu } & Sağlık Meslek Lisesi & 37 & 38,6 \\
\hline & Yüksekokul / Fakülte & 51 & 53,1 \\
\hline & Lisansüstü & 8 & 8,3 \\
\hline \multirow[t]{2}{*}{ Görev } & Sağlık Personeli & 49 & 51,0 \\
\hline & İdari Personel & 47 & 49,0 \\
\hline \multirow[t]{3}{*}{ Kurumda Çalışma Süresi } & $\leq 1 \mathrm{y} 1 \mathrm{l}$ & 22 & 22,9 \\
\hline & $2-9$ yil & 57 & 59,4 \\
\hline & $\geq 10 \mathrm{y} 11$ & 17 & 17,7 \\
\hline \multicolumn{4}{|c|}{ Kurumda Çalışma Süresi Ort. \pm ss: 4,79 $\pm 4,47$ (min: 1 - maks: 24 ) } \\
\hline \multirow[t]{3}{*}{ Meslekte Çalışma Süresi } & $\leq 3$ yil & 23 & 24,0 \\
\hline & $4-14$ y1l & 51 & 53,1 \\
\hline & $\geq 15$ y1l & 22 & 22,9 \\
\hline \multicolumn{4}{|c|}{ Meslekte Çalışma Süresi Ort. \pm ss: $9,51 \pm 6,67$ (min: 1 - maks: 27$)$} \\
\hline & & 96 & 100 \\
\hline
\end{tabular}

Tablo 2. Halkla ilişkiler faaliyetlerine ilişkin görüşlere yönelik tanımlayıcı istatistikler

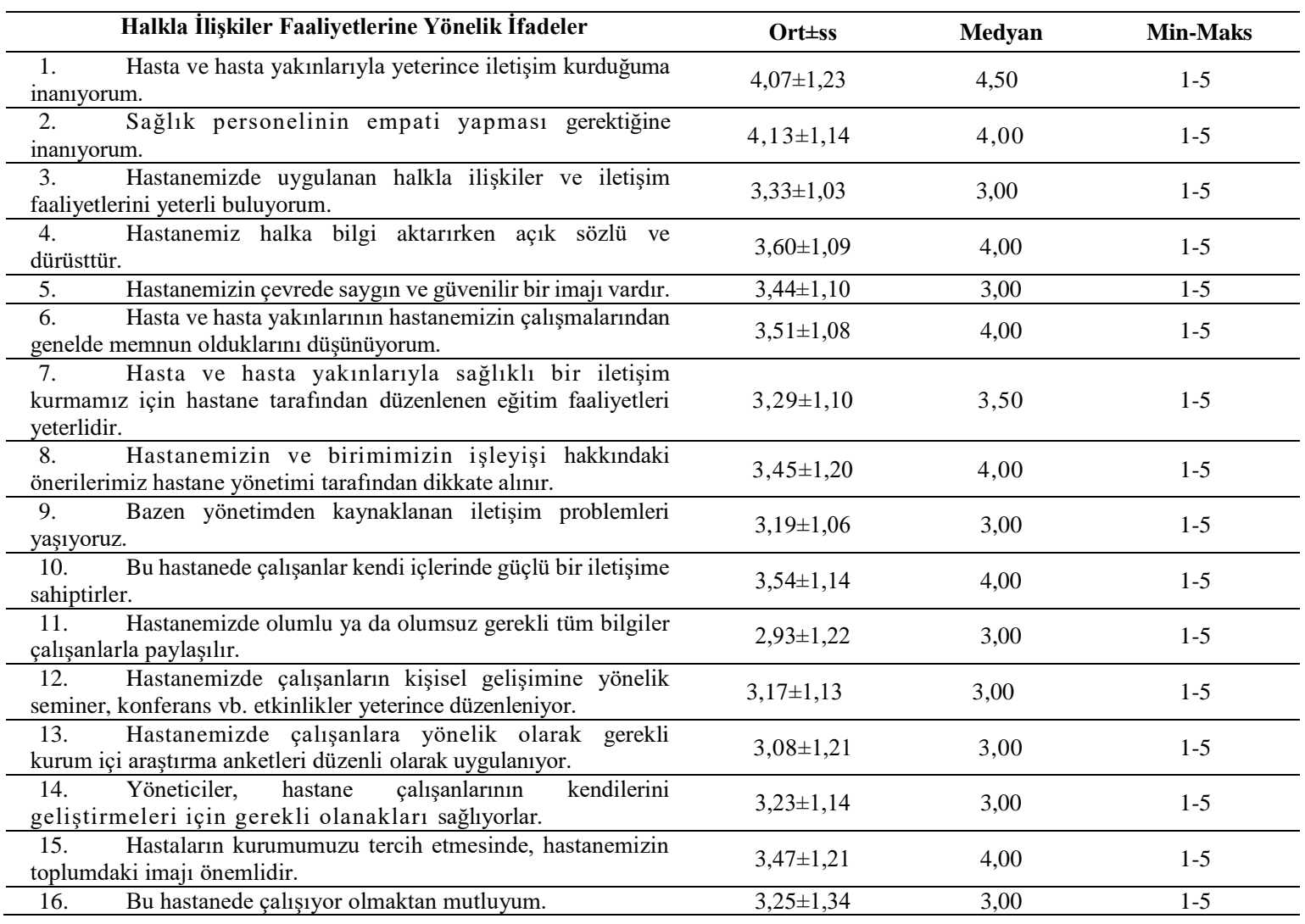


Nevşehir Bilim ve Teknoloji Dergisi (2021), 10(2) 135-143

Katılımcıların halkla ilişkiler faaliyetlerine yönelik ifadelerden yöneticilerinin hastane çalışanlarının kendilerini geliştirmeleri konusunda gerekli olanakları sağladıklarına yönelik görüşleri ile cinsiyetleri arasındaki fark istatistiksel olarak anlamlıdır. Buna göre erkeklerin medyan değeri kadınlardan daha yüksektir (Tablo 3).

Tablo 3. Katılımcıların cinsiyetlerine göre halkla ilişkiler faaliyetlerine ilişkin görüşleri

\begin{tabular}{|c|c|c|c|}
\hline & Kadın & Erkek & Test İstatistiği* \\
\hline Halkla İlişkiler Faaliyetlerine Yönelik İfadeler & $\begin{array}{c}\text { Medyan } \\
\text { (min-maks) }\end{array}$ & $\begin{array}{c}\text { Medyan } \\
\text { (min-maks) }\end{array}$ & (p değeri) \\
\hline $\begin{array}{l}\text { Yöneticiler hastane çalışanlarının kendilerini geliştirmeleri için } \\
\text { gerekli olanakları sağlıyorlar. }\end{array}$ & $\begin{array}{c}3,00 \\
(1,00-5,00)\end{array}$ & $\begin{array}{c}4,00 \\
(1,00-5,00)\end{array}$ & $\begin{array}{l}Z=-1,961 \\
(\mathbf{p}=\mathbf{0 , 0 5 0})\end{array}$ \\
\hline
\end{tabular}

* Mann Whitney U testi

Katılımcıların halkla ilişkiler faaliyetlerine yönelik ifadelerden bazı zamanlarda yönetimden kaynaklanan iletişim problemleri yaşandığına ilişkin görüşleri ile yaş grupları arasındaki fark istatistiksel olarak anlamlıdır. Farkın hangi gruplar arasında olduğunu anlamak için yapılan analizlere göre 26 ve altı yaş grubundaki çalışanlar ile 38 ve üzeri yaş grubundaki çalışanlar arasında fark vardır. 26 yaş ve altındaki çalışanların medyan değeri 38 yaş ve üzeri çalışanlardan daha yüksektir (Tablo 4).

Tablo 4. Katılımcıların yaş gruplarına göre halkla ilişkiler faaliyetlerine ilişkin görüşleri

\begin{tabular}{|c|c|c|c|c|}
\hline \multirow{2}{*}{$\begin{array}{c}\text { Halkla İlişkiler Faaliyetlerine Yönelik } \\
\text { İfadeler }\end{array}$} & $\leq 26$ yaş & 27-37 yaş & $\geq 38$ yaş & \multirow{2}{*}{$\begin{array}{c}\text { Test İstatistiği }{ }^{*} \\
\text { (p değeri) }\end{array}$} \\
\hline & $\begin{array}{c}\text { Medyan } \\
\text { (min-maks) }\end{array}$ & $\begin{array}{c}\text { Medyan } \\
\text { (min-maks) }\end{array}$ & $\begin{array}{r}\text { Medyan } \\
\text { (min-maks) }\end{array}$ & \\
\hline $\begin{array}{l}\text { Bazen yönetimden kaynaklanan iletişim } \\
\text { problemleri yaşıyoruz. }\end{array}$ & $\begin{array}{c}4,00 \\
(1,00-5,00)\end{array}$ & $\begin{array}{c}3,00 \\
(1,00-5,00)\end{array}$ & $\begin{array}{c}3,00 \\
(1,00-5,00)\end{array}$ & $\begin{array}{c}\mathrm{KW}=6,521 \\
(\mathbf{p}=\mathbf{0 , 0 3 8})\end{array}$ \\
\hline
\end{tabular}

* Kruskal Wallis testi

Katılımcıların "hasta ve hasta yakınlarıyla yeterince iletişim kurduğuna inanma”, "sağlık personelinin empati yapması gerektiğine inanma" ve "bu hastanede çalışıyor olmaktan dolayı mutlu olma” düşüncesine yönelik görüşleri ile kurumda çalışma yılları arasındaki fark istatistiksel olarak anlamlıdır. Farkın hangi gruplar arasında olduğunu anlamak için yapılan analizlere göre her üç görüşte de 2-9 yıldır kurumda çalışanlar ile 10 ve üzeri yıldır kurumda çalışanlar arasında fark vardır. Buna göre 2-9 yıldır kurumda çalışanların medyan değeri 10 ve üzeri yıldır kurumda çalışanlardan daha yüksektir (Tablo 5).

Tablo 5. Katılımcıların kurumda çalışma yılına göre halkla ilişkiler faaliyetlerine ilişkin görüşleri

\begin{tabular}{|c|c|c|c|c|}
\hline Halkla İlişkiler Faaliyetlerine Yönelik İfadeler & $\begin{array}{c}\leq 1 \text { yıl } \\
\text { Medyan } \\
\text { (min-maks) }\end{array}$ & $\begin{array}{c}2-9 \text { yıl } \\
\text { Medyan } \\
\text { (min-maks) }\end{array}$ & $\begin{array}{c}\geq 10 \text { yll } \\
\text { Medyan } \\
(\text { min-maks })\end{array}$ & $\begin{array}{l}\text { Test İstatistiği" } \\
\text { (p değeri) }\end{array}$ \\
\hline $\begin{array}{l}\text { Hasta ve hasta yakınlarıyla yeterince iletişim } \\
\text { kurduğuma inanıyorum. }\end{array}$ & $\begin{array}{c}4,00 \\
(1,00-5,00)\end{array}$ & $\begin{array}{c}5,00 \\
(1,00-5,00)\end{array}$ & $\begin{array}{c}4,00 \\
(1,00-5,00)\end{array}$ & $\begin{array}{l}\mathrm{KW}=6,619 \\
(\mathbf{p}=\mathbf{0 , 0 3 7})\end{array}$ \\
\hline $\begin{array}{l}\text { Sağlık personelinin empati } \\
\text { gerektiğine inantyorum. }\end{array}$ & $\begin{array}{c}4,00 \\
(1,00-5,00)\end{array}$ & $\begin{array}{c}5,00 \\
(1,00-5,00)\end{array}$ & $\begin{array}{c}4,00 \\
(1,00-5,00)\end{array}$ & $\begin{array}{c}\mathrm{KW}=15,614 \\
(\mathbf{p}=\mathbf{0 , 0 0 0})\end{array}$ \\
\hline Bu hastanede çalışıyor olmaktan mutluyum. & $\begin{array}{c}3,00 \\
(1,00-5,00)\end{array}$ & $\begin{array}{c}4,00 \\
(1,00-5,00)\end{array}$ & $\begin{array}{c}3,00 \\
(1,00-5,00)\end{array}$ & $\begin{array}{c}\mathrm{KW}=10,253 \\
(\mathbf{p}=\mathbf{0 , 0 0 6})\end{array}$ \\
\hline
\end{tabular}

* Kruskal Wallis testi

Katılımcıların, bazı zamanlarda yönetimden kaynaklanan iletişim problemleri yaşandığına ve hastaların kurumlarını tercih etmesinde hastanenin toplumdaki imajının önemli konusundaki görüşleri ile meslekte çalışma yılları arasındaki fark istatistiksel olarak anlamlıdır. Farkın hangi gruplar arasında olduğunu anlamak için yapılan analizlere göre her iki görüşte de 3 ve daha az yıldır meslekte çalışanlar ile 15 ve üzeri yıldır meslekte çalışanlar 
arasında fark vardır. Buna göre 3 ve daha az yıldır meslekte çalışanların medyan değeri 15 ve üzeri yıldır meslekte çalışanlardan daha yüksektir (Tablo 6).

Tablo 6. Katılımcıların Meslekte Çalışma Yılına Göre Halkla İlişkiler Faaliyetlerine İlişkin Görüşleri

\begin{tabular}{|c|c|c|c|c|}
\hline $\begin{array}{l}\text { Halkla İlişkiler Faaliyetlerine Yönelik } \\
\text { İfadeler }\end{array}$ & $\begin{array}{c}\leq 3 \text { yıl } \\
\text { Medyan } \\
\text { (min-maks) }\end{array}$ & $\begin{array}{c}\text { 4-14 yıl } \\
\begin{array}{c}\text { Medyan } \\
\text { (min-maks) }\end{array}\end{array}$ & $\begin{array}{r}\geq 15 \text { yıl } \\
\begin{array}{c}\text { Medyan } \\
\text { (min-maks) }\end{array}\end{array}$ & $\begin{array}{l}\text { Test İstatistiği }{ }^{*} \\
\text { (p değeri) }\end{array}$ \\
\hline $\begin{array}{l}\text { Bazen yönetimden kaynaklanan iletişim } \\
\text { problemleri yaşıyoruz. }\end{array}$ & $\begin{array}{c}4,00 \\
(1,00-5,00)\end{array}$ & $\begin{array}{c}3,00 \\
(1,00-5,00)\end{array}$ & $\begin{array}{c}3,00 \\
(1,00-5,00)\end{array}$ & $\begin{array}{r}\mathrm{KW}=8,922 \\
(\mathbf{p}=\mathbf{0 , 0 1 2})\end{array}$ \\
\hline $\begin{array}{l}\text { Hastaların kurumumuzu tercih etmesinde, } \\
\text { hastanemizin toplumdaki imajı önemlidir. }\end{array}$ & $\begin{array}{c}4,00 \\
(1,00-5,00)\end{array}$ & $\begin{array}{c}4,00 \\
(1,00-5,00)\end{array}$ & $\begin{array}{c}3,00 \\
(1,00-5,00)\end{array}$ & $\begin{array}{r}\mathrm{KW}=6,468 \\
(\mathbf{p}=\mathbf{0 , 0 3 9})\end{array}$ \\
\hline
\end{tabular}

* Kruskal Wallis testi

\section{Tartışma ve Sonuç}

Sağlık sunumunun en önemli bileşenlerinden biri olan hastanelerde kurumsal hizmet sunumu ve yönetim faaliyetlerinin güçlendirilmesi, hizmet sunumunun daha kaliteli ve yüksek standartlarda sunumu için önemlidir. $\mathrm{Bu}$ noktada gelişime yönelik planlamalar için halkla ilişkiler faaliyetlerine yönelik uygulamalar ve bu uygulamaların hastalar ve kurumda çalışan personel tarafından nasıl algılandığının incelenmesi gerekir. Personelin halkla ilişkiler biriminin ve bu birimin faaliyetlerinin önemini doğru anlaması halkla ilişkiler biriminin başarılı çalışmalar gerçekleştirmesi için son derece önemlidir [7].

Hastanelerde yürütülen halkla ilişkiler faaliyetlerine genellikle hastalar ve hasta yakınları için gözüyle bakılmaktadır. Üst yönetimin halkla ilişkilere bakış açısının değerlendirildiği bir çalışmada başhekime yöneltilen 'halkla ilişkiler etkinliklerinizin hedef kitleleri kimlerdir' sorusuna 'hasta ve hasta yakınları' cevabı alınmıştır [2]. Bir başka çalışmada da sağlık çalışanlarına göre halkla ilişkiler birimin en önemli görevinin hasta ve hasta yakınlarının sorunlarını çözmek olduğu belirlenmiştir [7]. Oysaki kurum çalışanları iç paydaş olarak etkin biçimde uygulanan halkla ilişkiler faaliyetleri açısından önemlidir.

$\mathrm{Bu}$ çalışma kurum çalışanlarının halka ilişkiler faaliyetlerine nasıl baktıkları ve algı düzeyini belirlemek amacıyla yapılmış olup kurumda çalışan personelin bu konuda orta ve bazı alanlarda yüksek düzeyde memnun olduğu bulunmuştur. Kurum çalışanlarına yöneltilen 'Hasta ve hasta yakınlarıyla yeterince iletişim kurduğuma inanıyorum' ve 'Să̆lık personelinin empati yapması gerektiğine inanıyorum' ifadeleri diğer ifadelere göre daha yüksek puan alırken, 'Hastanemizde olumlu ya da olumsuz gerekli tüm bilgiler çalışanlarla paylaşılır.' ifadesi daha düşük puanlanmıştır (Tablo 2).

Araştırmanın yürütüldüğü kurumda çalışanlar hastalara ve hasta yakınlarına olumlu yaklaşmaya ve onları anlamaya çaba göstermektedir. Halkla ilişkiler faaliyetlerini yürüten kurum ile hedef kitle arasındaki iletişimin sağlıklı ve olumlu zeminde ilerlemesi halkla ilişkiler faaliyetlerinin algılanması ve tabi ki kurum kimliğinin geliştirilmesi açısından önemlidir [2]. Yapılan başka bir çalışmada da personelin hasta ve yakınları ile olumlu iletişim ve empati kurduğu düşüncesi yüksek puan almıştır. Aynı çalışmada hastaların hastane çalışanlarından memnuniyeti de yüksek bulunmuştur [12]. Sağlık çalışanları hasta ve yakınlarına karşı empati kurması ve olumlu iletişimi güçlendirecek bir yaklaşımın sergilenmesi hasta memnuniyeti artmasına ve kurum imajının olumlu yönde gelişmesine katkı sağlayacaktır [11,14].

Araştırma bulgularına göre kurumda yönetim ile çalışanlar arasında bilgi aktarımı düşük düzeydedir. Oysaki çalışan memnuniyeti açısından kurumsal iletişim ve bilgilendirme önemlidir. Burada yönetimin çalışanlarına yaptığı kurum içi bilgilendirmenin yetersiz olduğu ya da yapılan bilgilendirmelerin iletişim 
Nevşehir Bilim ve Teknoloji Dergisi (2021), 10(2) 135-143

kanallarının etkin kullanılamaması ya da yetersizliği nedeniyle çalışanlara ulaşmadığı düşünülebilir. Gerçekleştirilen bir çalışmada 'Hastanemizde olumlu ya da olumsuz gerekli tüm bilgiler çalışanlarla paylaşılır.' ifadesinde idari bölümlerde memnuniyet daha yüksekken, sağlık çalışanlarında daha düşük bulunmuştur ve bu durum sağlık çalışanlarının yoğun temposu, çalışma saatlerinin düzensizliği ve hastalarla yüz yüze iletişimden kaynaklanan güçlüklerle karşı karşıya kalmalarına bağlanmıştır [2].

Çalışma kapsamında hem yaşı 26 ve daha küçük olan grupta hem de mesleki çalışma yılı daha küu̧ük (3 yıldan az veya eşit) olanlarda yönetim kaynaklı problem yaşama oranının yüksek olduğu belirtilmiştir (Tablo 4 ve Tablo 6). Bu durum mesleki tecrübenin az olması ve/veya kurum yapısını yeterli tanımamanın bir sonucu olabilir. Yaşı küçük olan, mesleki deneyimi az olan, çalışıı̆̆ kurumun yapısını yeterince tanımayan personelin daha az kurumsal bilgiye sahip oldukları, kurumu/yöneticileri tanımadıkları ve dolayısı ile yeterli/etkin iletişim kurmadıkları/kuramadıkları için bu düşüncede oldukları öngörülebilir.

Çalışmadan elde edilen verilere göre kurumda çalışma yılı 2-9 yıl olan personel ilgili kurumda çalışmaktan memnun olduğunu ifade etmiş̧ir. Kuruma yeni başlayanların (çalışma süresi<1 y1l) ya da uzun zamandır çalışanların (çalışma süresi>10 yıl) ise memnuniyet oranı orta derecede belirlenmiştir (Tablo 5). Yeni başlayanların henüz kuruma alışamadığı ya da benzeri nedenlerle sorun yaşadığı, 2 yıldan sonra çalışılan kuruma ve kuruma başvuran halka alıştıkları, uzun süredir çalışanlarında kurumdan ve koşullardan sıkılmaya başlaması muhtemel nedenler olabilir.

Hastanelerde hem kurumsal kimliğin hem de kurumsal imajın gelişiminde halkla ilişkiler faaliyetleri önemli bir yer tutar. Bu faaliyetlerin yönünü belirlemede ise hedef kitlenin düşünceleri ve algıları önemlidir. Kurum çalışanları hedef kitle kapsamında değerlendirilmeli ve mutlaka kurumla ilgili düşünce ve algıları belirlenmelidir. Bu doğrultuda elde edilen veriler ise kurumsal gelişim ve halkla ilişkiler bağlantılı araştırmageliştirme faaliyetleri için kullanılmalıdır.

Ayrıca çalışma verilerine göre çalışmanın yapıldığı kurumda halkla ilişkiler faaliyetlerinin ve bu faaliyetlerin çalsşan kurum personeli tarafından algılanmasının orta düzeyde olduğu görülmektedir. Kurumlarda olumlu ve olumsuz durumlarla ilgili bilgi akışının sağlanması ve geliştirici faaliyetlerin planlanması önemlidir. Kurumlarda olumlu iletişim kültürünün geliştirilmesi için çalışmalar yapılabilir.

Çalışma Ankara'nın bir ilçesinde bulunan 50 yataklı bir ilçe hastanesinde yapılımıştır. Araştırmanın yapıldığı hastanenin küçük olması, çalışan sayısının az olması ve sadece kendi ilçe halkına hizmet sunumu göz önünde bulundurulduğunda araştırmanın sınırlı bir alandaki verileri gösterdiği söylenebilir. Bu nedenle nüfus yoğunluğu, hastane büyüklüğü ve çalışan sayısı yönünden farklılık gösteren diğer ilçelerden benzer çalışmaların planlanması önerilebilir. Bu durum farklı ilçelerdeki hastanelerde halkla ilişkiler faaliyetlerinin çalışan gözü ile nasıl algılandı̆̆ belirlenme için temel bir bakış açısı oluşturacaktır. Daha sonra elde edilen veriler il merkezlerinde yer alan hastanelerle karşılaştırılarak ilçelerde halkla ilişkiler faaliyetlerinin geliştirilmesi çalışmalarına katkı sağlanabilir.

\section{Katkı Beyanı}

G.Y.: Çalışmanın dizayn edilmesi, veri analizi ve makale yazımı. B.G.: Çalışmanın dizayn edilmesi, çalışma verilerinin toplanması ve makale yazımı. D.T.A.: Çalışmanın dizayn edilmesi, verilerin yorumlanması ve makale yazımı. 
6. Kaynaklar

[1] Işık M., Konur Ö. "Hastanelerde halkla ilişkiler: Kayseri'deki özel hastaneler üzerine bir çalışma" Humanities Sciences, 5, 373-383, 2010

[2] Bahadır Ö. "Hastanelerde halkla ilişkiler uygulamalarına yönelik bir araştırma” Marmara Üniversitesi, Sosyal Bilimler Enstitüsü, Yayınlanmamış Yüksek Lisans Tezi, İstanbul, 2010

[3] Çelebi E. "Sağlık kuruluşlarında halkla ilişkilein etkinliğini ölçme: özel ve kamu sağlık kuruluşlarının karşılaştırılması" Anadolu Üniversitesi Sosyal Bilimler Dergisi, 21, 81-98, 2021

[4] Aslan M, M. (2018). “Özel Sektör ve Özel Sağlık Kuruluşlarında Halkla İlişkiler” SEGA Matbaacılık, 2011

[5] Tengilimoğlu D., Kılıç, M. "Hastanelerde halkla ilişkiler: sağlık bakanlığı, üniversite, ssk ve özel hastane yöneticilerinin halkla ilişkiler uygulamalarına yönelik ampirik bir araştırma". Hacettepe Üniversitesi İktisadi ve İdari Bilimler Fakültesi Dergisi, 22, 175-200, 2004

[6] Schmitz, A. "Publis Relations", https://2012books.lardbucket.org/pdfs/public-relations.pdf, Erişim tarihi Eylül 20, 2012

[7] Duğan Ö., Uludağ A. "Sağlık çalışanlarının halkla ilişkilere bakış: selçuk üniversitesi tıp fakültesi örneği" Selçuk Üniversitesi Sosyal Bilimler Enstitüsü Dergisi, 34, 41-51, 2015

[8] Jefkins, F. “Public Relations Techniques” Butterworth-Heinemann Ltd., London, 1995

[9] Güllüpunar M., D. "Bir halkla ilişkiler uygulaması olarak hastanelerde hasta karşılama hizmetlerinin kurumsal itibara etkisi: kamu hastaneleri üzerine bir inceleme" Gümüşhane Üniversitesi İletişim Fakültesi Elektronik Dergisi, 4, 898-925, 2016

[10] Uyanık, J. "Hastanelerde Halkla İlişkiler Fonksiyonuna Bakış: Adana Bölgesinde Bir Uygulama", Yüksek Lisans Tezi, Çağ Üniversitesi Sosyal Bilimler Enstitüsü, Mersin. 2011.

[11] Balta Petekoğlu F. "Halkla İlişkilere Giriş" Marmara Üniversitesi İletişim fakültesi, Yayın No: 1. İstanbul, 1993

[12] Ak M. “Firma ve Markalarda Kurumsal Kimlik ve İmaj” Iş11 Ofset, İstanbul, 1998

[13] Kurdar Y. "The role of Public relations for image Creating in Health services: A sample patient satisfaction survey" Health Marketing Quarterly, 24, 33-53, 2007

[14]. Göktaş B., Yeşilaydın G., Özkan O. "Hastaların halkla ilişkiler faaliyetlerine bakış açılarının incelenmesi” Business \& Management Studies: An International Journal, 5, 137-153, 2017 